\title{
HEAD TRAUMA IN A CHILD WITH STURGE-WEBER SYNDROME OVERLAPPING KLIPPEL-TRENAUNAY SYNDROME
}

\author{
Aleksandar Kostić1,2, Tatijana Tošić2,3, Radisav Mitić1,2, Miša Radisavljević1,2, \\ Predrag Milošević ${ }^{1,2}$, Slavko Živković1,2, Bojan Stanojević1,2
}

\begin{abstract}
Here we present a case of a 10-year-old girl who was diagnosed with SWS at birth. The history of seizures and transient right-sided hemiparesis dates from the neonatal period. Portwine stains on the face, right hand and foot were present from the birth of the child which may suggest overlapping with KTS. When the girl suffered mild head trauma, some hours after, vomiting, aphasia, and hemiplegia occurred. The patient was admitted to the Clinic of Neurosurgery and after observation, she was commenced on symptomatic and antiepileptic therapy. Within the following 24 hours, aphasia resolved and hemiplegia turned into mild hemiparesis. As the neurological status improved and the patient felt better, after two more days of observation, the child was discharged from the hospital.
\end{abstract}

Acta Medica Medianae 2021;60(1):74-78.

Key words: Sturge-Weber syndrome, Klippel-Trenaunay syndrome, head trauma

${ }^{1}$ Clinic of Neurosurgery, Clinical Center Niš, Niš, Serbia

2University of Niš, Faculty of Medicine, Niš, Serbia

${ }^{3}$ Clinic of Internal Pediatric Disease, Pediatric neurology, Clinical Center Niš, Niš, Serbia

Contact: Aleksandar Kostić

48 Dr Zoran Djindjić Blvd., 18000 Niš, Serbia

E-mail: aleko018@yahoo.co.uk

\section{Introduction}

Sturge-Weber syndrome (SWS) is a rare congenital neurological and skin disorder. It is often associated with leptomeningeal angioma, port-wine stains on the face, and glaucoma. These features can vary in severity though not all individuals have all three elements. An estimated frequency of SWS occurrence is 1 per 50,000 live births, although some experts believe that there are many unidentified cases (1).

Neurological symptoms often involve temporary hemiparesis $(25-60 \%)$, hemianopsia $(40-45 \%)$, glaucoma (30-70\%), migraine headaches $(40-60 \%)$, and seizures $(75-90 \%)(2)$. Seizures that begin in infancy may worsen with age. They usually happen on the side of the body opposite the birthmark and vary in severity. The transient worsening of the hemiplegia manifests with seizures and episodes resembling hemiplegic migraine.
Klippel-Trenaunay syndrome (KTS) is another very rare phacomatosis, characterized by a triad of vascular malformation, venous varicosity, and hyperplasia of soft tissue and bone of the affected limb (3). Just several cases of overlap between SWS \& KTS have been encountered up to now (3-5). To our knowledge, this is the first published case report of a child with an overlap between SWS \& KTS who had mild head trauma.

Brain trauma is often associated with seizures, but children are particularly prone to head injuries. A syndrome of transient hemiplegia following minor head trauma is described in healthy children. The acute effects can be severe with hemiparesis, altered consciousness, and evidence of raised intracranial pressure but usually with full recovery (6). Hemiplegia in children with SWS after a mild head injury is known to occur in up to one-fifth of cases (7).

\section{Case report}

Here we present a case of a 10-year-old girl, who was diagnosed with SWS at birth. The history of seizures and transient mild right-sided hemiparesis date from the neonatal period. Port-wine stains on the face, right hand and foot were present from the birth of the child (Figure 1A, B, C, and D), which may suggest overlapping with KTS.

The girl was successfully treated for status epilepticus two months before the mild head trauma. The patient was treated with valproic acid (Eftil) in the dose of $500 \mathrm{mg}$ twice a day and carbamazepine (Tegretol) $400 \mathrm{mg}$ twice a day. 


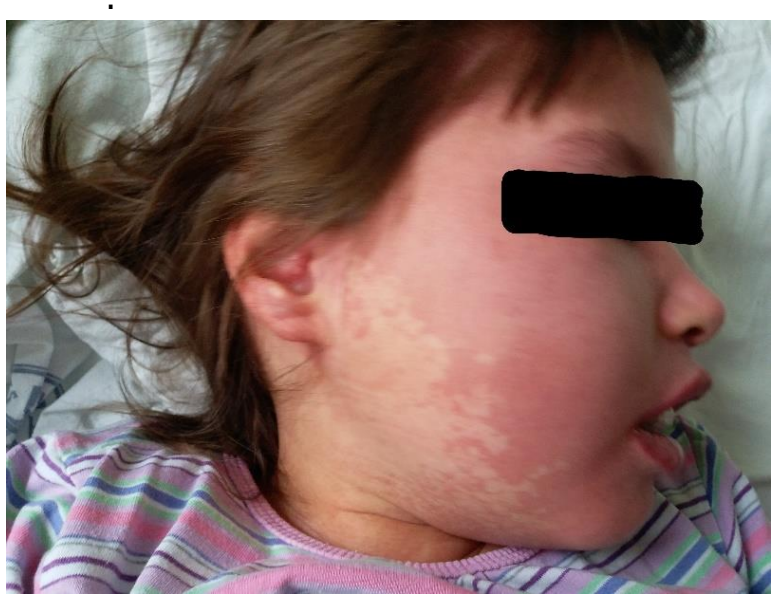

A

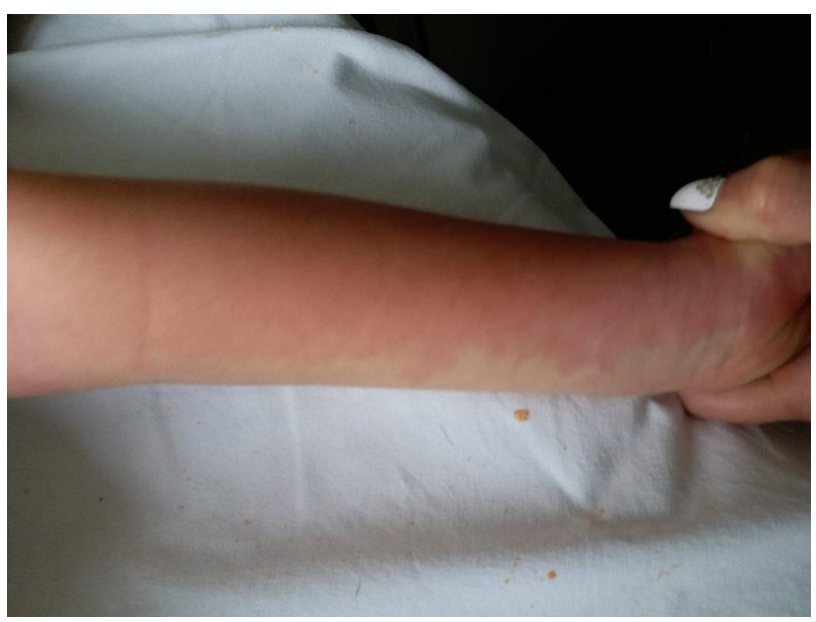

C

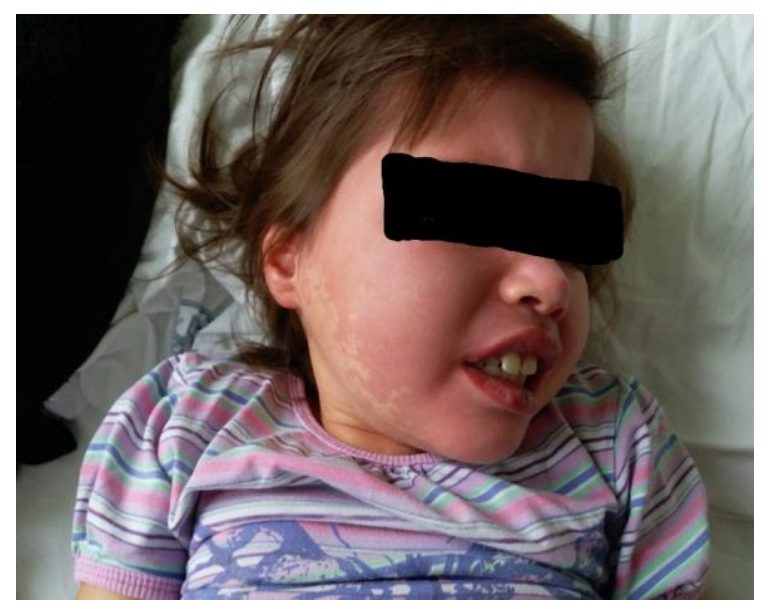

B

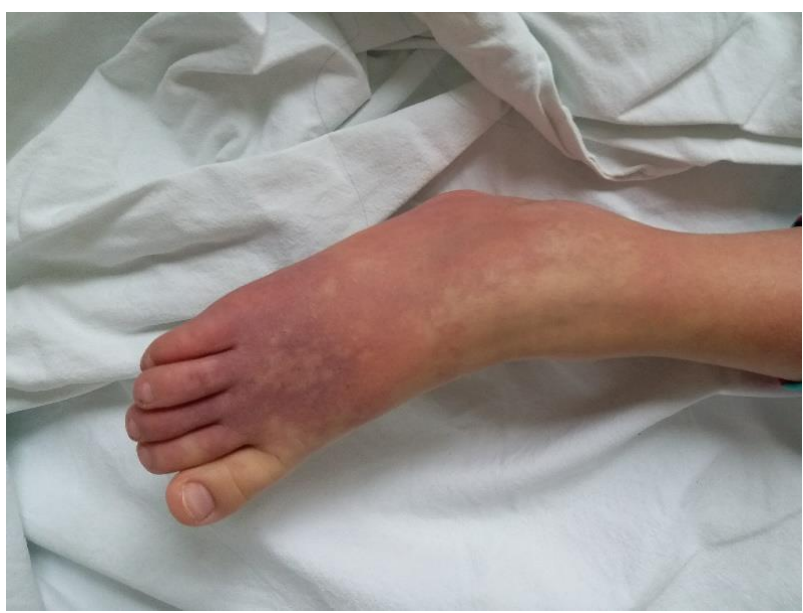

D

Figure 1. Phacomatosis present in SWS on the right side as a port-wine stain of the face $(A, B)$, and present in Klippel-Trenaunay syndrome on the hand and the foot (C and D)

The incident occurred in school when she accidentally hit the head against the wall. There was no loss of consciousness, but some hours after, vomiting, aphasia, and hemiplegia occurred. That was the reason for transferring the child to the Neurosurgery Department. A brain CT showed no brain or bone trauma findings. The bilateral brain atrophy with calcification was present (Figure 2A and 2B).

During hospitalization, the girl was treated with analgesics (Paracetamol $500 \mathrm{mg}$ per os, three times a day), and intensive rehydration therapy. Antiepileptic therapy was continued as previously. The serum level of valproic acid and carbamazepine remained at required values inside the wanted range, namely, at $57.5 \mathrm{mg} / \mathrm{ml}$ and $4.1 \mathrm{mg} / \mathrm{ml}$ respectively. In the first 24 hours, aphasia resolved and hemiplegia returned to mild hemiparesis. As the neurological status resolved to previous and the patient felt better, after two more days of observation, the child was discharged from the hospital after consultation with a pediatric neurologist. After a month, at the ambulatory follow-up, the patient had normal neurological findings. EEG showed normal basic activity, in the left temporal region some delta wave activity, without epileptic readiness.

Three years after mild head trauma, the child was in good clinical condition, without neurological deficit, and with a history of a seizure-free period of more than two years. 


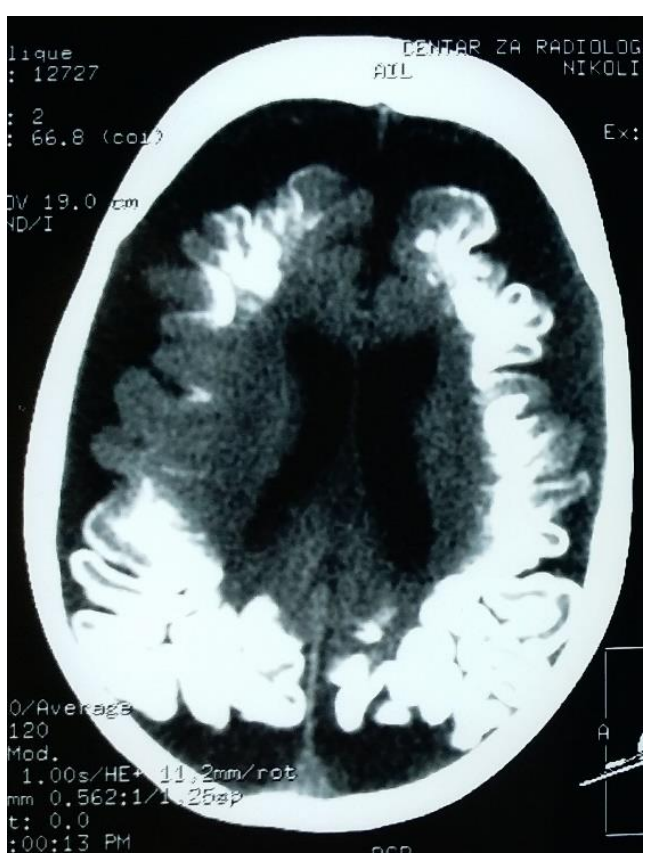

A

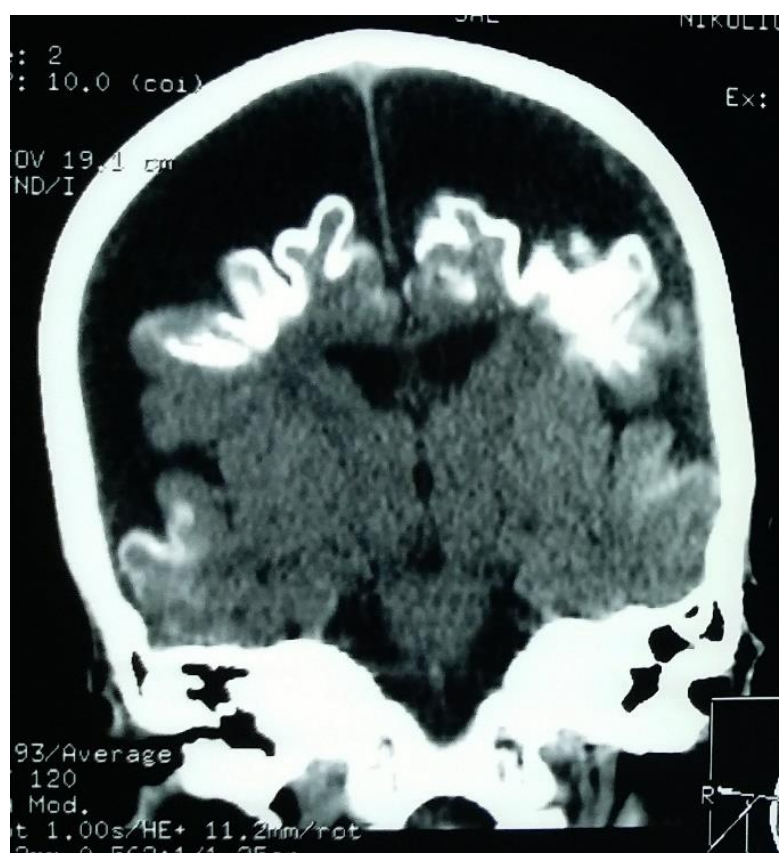

B

Figure 2. A. Brain CT axial slice presents bilateral hemisphere atrophy and calcification and B. coronal slice

\section{Discussion}

The child in our case report had two out of three signs of SWS. Preserved vision and negative ophthalmological exam eliminated glaucoma. The port-wine birthmark was located on the face, typically on the forehead, temple, eyelid, but also both cheeks. The port-wine birthmark is usually only on one side of the face but can be on both sides. Over time, the skin within the port-wine birthmark can darken and thicken. It is not common for SWS patients to have a port-wine birthmark on arms or legs.

Brain CT showed discrete signs of preexisting leptomeningeal angioma in the left temporoocipital region. Leptomeningeal angioma, can affect one or both sides of the brain, impair blood flow in the brain and lead to atrophy and calcification in the brain below the angioma. Its most usual presentation is hemiconvulsion, which may lead to hemiplegia. Two months before the admission, the girl had a seizure attack which was followed by transient left-sided hemiparesis. At the admission to our clinic, the patient had localized small contusion of the epicranial tissue on the forehead, which was hidden with a port-wine birthmark, and there was no history or signs of previous seizure.

In patients with Klippel-Trenaunay syndrome, the port-wine stain usually covers part of one limb. In our patient, there were some features of each syndrome and no glaucoma or hypertrophy of bones or soft tissue of limbs.
Zolkipli et al. showed in their study 5 pediatric cases (aged from 10 months to 12 years) of SWS that had complete recovery of their neurologic deficit sometime after mild head trauma. In these patients, as well in our case, the episodes of head trauma appeared accidental and not caused by a seizure. The period in which the recovery occurred was from 30 minutes to two weeks. The onset of the neurologic deficit was noted from immediately after the trauma up to 24 hours (8).

These are consistent with the case of our patient who developed neurological deficits a few hours later and it lasted for less than 24 hours. There was also a case that presented the diagnostic need for MRI, which had to be done to rule out venous malformation, as the previously done brain CT misdiagnosed it as brain contusion (7). During the hospitalization of our patient at the Clinic of Neurosurgery, brain CT was proved to be an adequate diagnostic measure, as very soon recovery occurred.

CT findings showed astonishing brain atrophy in the child, with diffuse bilateral gyral calcification. This atrophy may be a precondition for more extensive acceleration-deceleration brain injuries. Bridging veins are stretched in brain atrophy and prone to laceration and formation of acute subdural hematomas, a fact usually associated with the geriatric population (9). Atrophy combined with calcification also implies dysfunction of the cortical vascular network along with superficial cortical veins with persistent high flow to the deep venous system. This insufficient venous return system results in vascular 
stasis with chronic hypoxia of the brain. This leads to morphologic changes of the deep venous wall fibrosis and thickening and insufficient blood flow throw its collaterals. The dysfunction or absence of vein collaterals makes the brain prone to congestioninduced hypoxia even after mild trauma. This course of histological and physiological events has its genetic background (10). In 2013 a somatic nonsynonymous single-nucleotide variant (c.548G $\rightarrow A$, p.Arg183GIn) in GNAQ was identified (11). This $\mathrm{R} 183 \mathrm{Q}$ mutation is associated with most of the Sturge-Weber syndrome tissue and isolated portwine birthmark samples tested. In the study of Huang et al., the R183Q mutation of the GNAQ gene was identified as a probable cause for familial SWS through the sequencing of all of the exons of the GNAQ and RASA1 genes in 3 patients with familial
SWS. The functional study confirmed that the genetic mutation R183Q affected the functions of the encoded protein, Gaq (12). On the other hand, some results are implying that KTS may be associated with a translocation at $t(8 ; 14)(q 22.3 ; q 13)(13)$.

\section{Conclusion}

Based on our experiences mentioned above, we can conclude that even mild head trauma can complicate preexisting SWS and cause transient hemiparesis. Overlapping of two mentioned syndromes does not make substantial diagnostic or therapeutic differences compared to the treatment of SWS alone. Observation, symptomatic therapy, and continuation of antiepileptic therapy are mandatory.
1. Haslam R. Neurocutaneous syndromes. In: Nelson WE, Behrman RE, Kliegman RM, Arvin AM, eds. Nelson textbook of pediatrics, $15^{\text {th }}$ ed. Philadelphia: W. B. Saunders; 1996: 1707-9.

2. Thomas-Sohl KA, Vaslow DF, Maria BL. Sturge-Weber syndrome: a review. Pediatr Neurol. 2004;30(5):30310. [CrossRef] [PubMed]

3. Barek L, Ledor S, Ledor K. The Klippel-Trenaunay syndrome: A case report and review of the literature. Mt Sinai J Med 1982;49:66-70. [PubMed]

4. Rahman M, Rahman S, Rahman M, Akhter S, Kawser C. Overlapping of Sturge Weber syndrome and Klippel Trenaunay Weber syndrome. Mymensingh Med J 2008;17(1):78-81. [PubMed]

5. Purkait R, Samanta T, Sinhamahapatra T, Chatterjee M. Overlap of sturge-weber syndrome and klippeltrenaunay syndrome. Indian J Dermatol 2011;56(6): 755-7. [CrossRef] [PubMed]

6. Snoek JW, Minderhoud JM, Wilmink JT. Delayed deterioration following mild head injury in children. Brain 1984;107 (Pt 1):15-36. [CrossRef] [PubMed]

7. Ahmed S, Paul SP. Hemiplegia Following Mild Head Injury in a Child with Sturge-Weber Syndrome - A Diagnostic Dilemma. J Coll Physicians Surg Pak 2016; 26(8):704-6. [PubMed]

8. Zolkipli Z, Aylett S, Rankin PM, Neville BG. Transient exacerbation of hemiplegia following minor head trauma in Sturge-Weber syndrome. Dev Med Child Neurol 2007;49(9):697-9. [CrossRef] [PubMed]

9. Kostić A, Kehayov I, Stojanović N, Nikolov V, Kitov B, Milošević $P$, et al. Spontaneous chronic subdural hematoma in elderly people - Arterial hypertension and other risk factors. Journal of the Chinese Medical Association 2018;81(9):781-6. [CrossRef] [PubMed]

10. Comi AM. Pathophysiology of Sturge-Weber syndrome. J Child Neurol 2003;18(8):509-16. [CrossRef] [PubMed]

11. Shirley MD, Tang $H$, Gallione $C J$, Baugher JD, Frelin $L P$, Cohen $B$, et al. Sturge-Weber syndrome and portwine stains caused by somatic mutation in GNAQ. N Engl J Med 2013;368:1971-9. [CrossRef] [PubMed]

12. Huang $Z$, Li $Y$, Zhao $Z$, Hu J, Tong $X$, Chen $X$ et al. GNAQ mutation R183Q as a potential cause of familial Sturge-Weber syndrome: A case report. Oncol Lett 2017;13(4):V2665-2669. [CrossRef] [PubMed]

13. Wang $Q$, Timur AA, Szafranski $P$, Sadgephour $A$, Jurecic V, Cowell J et al. Identification and molecular characterization of de novo translocation $t(8 ; 14)$ (q22.3;q13) associated with a vascular and tissue overgrowth syndrome. Cytogenetics and cell genetics 2001;95(3-4):183-8. [CrossRef] [PubMed] 


\title{
POVREDA GLAVE U DETETA SA STURGE-WEBER I KLIPPEL-TRENAUNAY SINDROMOM
}

\author{
Aleksandar Kostić1,2, Tatijana Tošić2,3 ,Radisav Mitić1,2, Miša Radisavljević1, ${ }^{1,2}$, \\ Predrag Milošević1,2, Slavko Živković1, ${ }^{1,2}$ Bojan Stanojević1,2
}

${ }^{1}$ Klinika za neurohirurgiju, Klinički centar Niš, Niš, Srbija

${ }^{2}$ Univerzitet u Nišu, Medicinski fakultet, Niš, Srbija

${ }^{3}$ Klinika za dečije interne bolesti, Dečija neurologija, Klinički centar Niš, Niš, Srbija

Kontakt: Aleksandar Kostić

Bulevar dr Zorana Đinđića 48, 18000 Niš, Srbija

E-mail: aleko018@yahoo.co.uk

U radu se prezentuje slučaj desetogodišnje devojčice, kojoj je dijagnostikovan SturgeWeber sindrom (SWS) na rođenju. Epileptični napadi i prolazne hemipareze datiraju još od neonatalnog perioda. Od rođenja su prisutni angiomi lica, desne ruke i stopala, što sugeriše na udruženost sa Klippel-Trenaunay sindromom (KTS). Nakon blage povrede glave, nekoliko sati kasnije javalju se povraćanje, afazija i hemiplegija. Dete je primljeno na lečenje na Kliniku za neurohirurgiju, radi posmataranja i davanja simptomatske i antiepileptične terapije. Unutar sledećih 24 sata, neurološki nalaz se bitno popravlja i nakon dva dana dalje opservacije, dete se otpušta iz bolnice.

Acta Medica Medianae 2021;60(1):74-78.

Ključne reči: Sturge-Weber sindrom, Klippel-Trenaunay sindrom, povreda glave 